\title{
STRONGYLOIDIASIS IN CLINICAL PRACTICE: CHALLENGES IN DIAGNOSTICS AND TREATMENT (BRIEF REVIEW AND CLINICAL OBSERVATIONS)
}

\author{
A.K. Tokmalaeva, G.M. Kozhevnikova ${ }^{a}$, V.D. Zavoikin ${ }^{b}$, N.I. Tumolskaya ${ }^{\text {, }}$, \\ N.A. Polovinkina ${ }^{a}$, V.V. Konnov ${ }^{a}$, V.P. Golub ${ }^{a}$, T.V. Kharlamova ${ }^{a}$, K.C. Emerole ${ }^{a}$ \\ ${ }^{a}$ Peoples' Friendship University of Russia (RUDN University), Moscow, Russian Federation \\ ${ }^{b}$ I.M. Sechenov First Moscow State Medical University, Moscow, Russian Federation
}

\begin{abstract}
High priority of soil-transmitted helminths worldwide and in the Russian Federation is due to their vast distribution and the severe pathological features they induce in humans. Recently, it was observed that awareness of clinicians regarding this disease category was markedly decreased, although no significant decline of the disease occurrence has been recorded, whereas rate of imported cases of parasitic diseases including soil-transmitted helminths like strongyloidiasis mainly originating from subtropical or tropical countries rose in non-endemic regions. Lack of alertness on diseases like strongyloidiasis impedes timely diagnostics and treatment. Global prevalence of strongyloidiasis was estimated to range within 30-100 million people, however the World Health Organization (WHO) suggests that it was underestimated as precise data in endemic countries remain unknown. The occurrence of these helminths has been recorded in regions of temperate-continental climate: Western Ukraine, Belarus, Moldova, the Caucasus, Central Asia, as well as in Eastern Europe and the Mediterranean region. In the Russian Federation locally acquired infections are frequently recorded in the Krasnodar Territory and Rostov Region. Here, based on multi-year experience in management of patients with strongyloidiasis we present our data and brief review of publications and systematic literature related to the challenges of its clinical picture, diagnostics and treatment. Life cycle, basic biological parameters of free-living helminth in nature and distinctive features of autoinfection related to strongyloidiasis were reviewed. Special attention was paid to the risk of developing severe forms (hyperinfection and disseminated strongyloidiasis) especially in immunocompromised hosts: HIV infection, radiotherapy followed by chemotherapy, long-term corticosteroid use. Difficulties in diagnosing Strongyloides stercoralis infection are due to its polymorphic and non-specific clinical manifestations, as well as the lack of clinical knowledge and awareness about the disease. Clinical importance of parasitological methods for larvae detection was underlined. It was noted that the drug of choice in therapy of strongyloidiasis is ivermectin unapproved yet in Russia, whereas albendazole as an alternative drug exerts poorer efficacy, justifying a need to repeat treatment courses to establish full recovery from the disease.
\end{abstract}

Key words: strongyloidiasis, Strongyloides stercoralis, immunodeficiency, autoinfection, hyperinfection, disseminated strongyloidiasis, Baermann funnel technique, Ivermectin.

\section{Адрес для переписки:}

Харламова Татьяна Владимировна

117198, Россия, Москва, ул. Миклухо-Маклая, 6,

ФГАОУ ВО Российский университет дружбы народов.

Тел.: 8910 490-91-16.

E-mail: tatykharlam@yandex.ru

\author{
Contacts: \\ Tatyana V. Kharlamova \\ 117198, Russian Federation, Moscow, Miklukho-Maklay str., 6 , \\ Peoples Friendship University of Russia (RUDN University). \\ Phone: +7 910 490-91-16. \\ E-mail: tatykharlam@yandex.ru
}

\section{Citation:}

Tokmalaev A.K., Kozhevnikova G.M., Zavoikin V.D., Tumolskaya N.I., Polovinkina N.A., Konnov V.V., Golub V.P., Kharlamova T.V., Emerole K.C. Strongyloidiasis in clinical practice: challenges in diagnostics and treatment (brief review and clinical observations) // Russian Journal of Infection and Immunity = Infektsiya i immunitet, 2020, vol. 10, no. 4, pp. 664-670. doi: 10.15789/2220-7619-SIP-1224 


\section{СТРОНГИЛОИДОЗ В КЛИНИЧЕСКОЙ ПРАКТИКЕ: ВОПРОСЫ ДИАГНОСТИКИ И ЛЕЧЕНИЯ (КРАТКИЙ ОБЗОР И КЛИНИЧЕСКИЕ НАБЛЮДЕНИЯ)}

Токмалаев А.К. ${ }^{\text {, }}$ Кожевникова Г.М. ${ }^{1}$, Завойкин В.Д. ${ }^{2}$, Тумольская Н.И. ${ }^{2}$, Половинкина Н.А. ${ }^{1}$, Коннов В.В. ${ }^{1}$, Голуб В.П. ${ }^{1}$, Харламова Т.В. ${ }^{1}$, Емероле К.Ч. ${ }^{1}$

${ }^{1}$ Российский университет дружбы народов, Москва, Россия

${ }^{2}$ Первый Московский государственный медицинский университет им. И.М. Сеченова, Москва, Россия

Резюме. Актуальность проблемы геогельминтозов, как в мире, так и в Российской Федерации, обусловлена их широким распространением и вызываемыми ими серьезными патологическими изменениями в организме человека. В последнее время наблюдается заметное снижение информированности практических врачей об этой категории болезней, хотя уровень заболеваемости в стране не снижается, а завоз паразитарных болезней, включая различные гельминтозы, в том числе стронгилоидоз, неуклонно нарастает. Слабая настороженность к этим болезням препятствует своевременной диагностике и лечению. В Российской Федерации стронгилоидоз относится к редким нозологическим формам (уровень заболеваемости не превышает 1,0 на 100 тыс. населения) и его регистрируют в общей строке «другие гельминтозы». Наряду с регионами с тропическим и субтропическим климатом ареалы распространения этого гельминта существуют в районах с умеренным климатом: в западных областях Украины, Белоруссии, Молдове, на Кавказе и в Средней Азии, а также в Восточной Европе и Средиземноморском регионе. В РФ случаи местного заражения чаще регистрируются в Краснодарском крае и Ростовской области. Авторы, имеющие многолетний опыт ведения больных стронгилоидозом, представили анализ собственных наблюдений и краткий обзор современной научной и методической литературы по проблемам клиники, диагностики и лечения гельминтоза. Рассмотрены особенности биологии возбудителя - Strongyloides stercoralis: наличие в жизненном цикле свободноживущих в природе и паразитирующих в организме человека взрослых гельминтов, возможность аутоинвазии, из-за которой болезнь длится годами и не завершается выздоровлением. Обращено внимание на существенные изменения в клинике гельминтоза на современном этапе, в том числе в сторону тяжелых форм (гиперинвазивный и генерализованный стронгилоидоз), что обусловлено распространением состояния иммунодефицита у людей (ВИЧ/СПИД, широкое применение ГКС и по другим причинам). Трудности клинической диагностики, частые ошибки в первичном диагнозе объясняются как полиморфизмом клиники данного гельминтоза, так и недостаточной информированностью практических врачей о стронгилоидозе. В диагностике отмечено ведущее значение паразитологических методов, направленных на обнаружение личинок (но не яиц) гельминта. Указано, что средством выбора для лечения является известный антигельминтный препарат «Ивермектин», который в РФ не зарегистрирован. В практике для этих целей используется «Албендазол», который недостаточно эффективен, поэтому, как правило, возникает необходимость проведения повторных циклов лечения.

Ключевые слова: стронгилоидоз, Strongyloides stercoralis, иммунодефицит, аутоинвазия, гиперинвазия, генерализованный стронгилоидоз, воронковый метод Бермана, «Ивермектин».

The public health and clinical significance of soiltransmitted helminths worldwide and in the Russian Federation is due to their vast distribution and the severe pathological features they induce in humans. Recent observation has indicated lack of awareness among clinicians regarding this disease category, although no significant decline of the disease occurrence has been recorded. Imported cases of parasitic diseases including soil-transmitted helminths like strongyloidiasis which mostly originate from countries in subtropical or tropical regions are increasing in non-endemic regions. Lack of information and awareness about diseases like strongyloidiasis impedes prompt diagnosis and treatment. Worldwide prevalence of strongyloidiasis has long been estimated to be between 30 and 100 million people, however the World Health Organization (WHO) suggest that this is an underestimation as precise data on prevalence are unknown in endemic countries [6, 9, 15, 23].

In the Russian Federation strongyloidiasis is considered a rare disease, (the incidence rate does not exceed 1 case per 100,000 population) therefore it is classified as «other helminthiasis». The occurrence of these helminths has been recorded in regions of temperate-continental climate: Western Ukraine, Belarus, Moldova, the Caucasus, Central Asia, as well as in Eastern Europe and the Mediterranean region. In the Russian Federation locally acquired infections are frequently recorded in the Krasnodar Territory and Rostov Region [2, 13, 14].

Strongyloidiasis is characterized by several features in the pathogenesis and clinical course. Immunocompromised individuals such as human immunodeficiency virus infection (HIV infection) are the most vulnerable population at risk for developing life-threatening clinical syndromes associated with the disease $[4,6,10,11,22]$.

Strongyloidiasis is caused by 2 species of the intestinal nematode Strongyloides. The most common and globally distributed human pathogen of clinical importance is Strongyloides stercoralis, S. fuelleborni occurs exclusively in humans in Africa and New Papua Guinea. S. stercoralis (intestinal nematode) - is a dioecious parasite that belongs to the genus of parasitic nematodes. The disease was first recognized in 1876 by the French physician Louis 
Alexis Normand. He had tested stool specimens taken from French troops suffering from severe, persistent diarrhea who had returned from Cochin China (Vietnam). The disease was known for many years as "Cochin-China diarrhea" [14, 22].

Strongyloides stercoralis is a soil-transmitted helminth with a more complex life cycle than that of most nematodes because it alternates between freeliving cycle of development in the soil and parasitic life cycle in humans. The life cycle of $S$. stercoralis is basically composed of adult worms, rhabditiform larvae and filariform larvae (filaria). Adult female worms embed in the small intestinal mucosa (sometimes in the pancreatic duct, biliary tract and crypts of Lieberkühn). Female adult worms that burrow into the submucosa of the small bowel asexually produce eggs. The eggs hatch into rhabditiform larvae, which are released into the lumen of the intestine and are excreted along with stool, into the environment (soil and water) later transforming in to filariform. In the regions of warm and humid climate, larval development of parasites in the environment to the invasive stage occurs in all seasons of the year unlike in regions of temperate-continental climate. The filariform larvae then can penetrate the skin of a human host to begin the second life cycle, called the parasitic cycle, or direct cycle. After penetration, the filariform larvae enter the venous circulation, and are transported to the lungs invading the alveolar spaces. They then migrate from the bronchial tree to the pharynx, are swallowed, and end up in the small intestine. In the intestine, they molt twice and become adult female worms which produce eggs that develop into rhabditiform larvae. S. stercoralis is unique among intestinal nematodes in its ability to complete its life cycle within the host through an asexual autoinfective cycle, allowing the infection to persist in the host indefinitely. In autoinfection some rhabditiform larvae transform into invasive filariform larvae before being excreted. As such, they are capable of reinfecting the host by invading the intestinal wall or the perianal skin. Under some conditions associated with immunosuppression or underlying gastrointestinal disorders (constipation, diverticulitis) this autoinfective cycle can become amplified into a potentially fatal hyperinfection syndrome, characterized by severe complications. There is evidence implicating the sexual transmission of Strongyloides stercoralis among homosexual men. It is important to note that laboratory safety measures mandated at most institutions are necessary to protect against infection with $S$. stercoralis $[4,6,14,19]$.

In the early stage of the disease, pathological changes in tissues and organs are due to the host to the activity and metabolic products of the parasite. Migration of the filariform larvae from the intestine into the portal vein system and then the pulmonary circulatory system may lead to the development of bronchopneumonia, asthmatic bronchitis, and eosinophilic pulmonary infiltrates. The parasite reach- es the intestine 20-30 days after the initial infection. Invasion of the intestine is accompanied by its mucosal damage, hemorrhage, eosinophil infiltration, erosion, and often ulcers. Granulomas of various organs (gastric, liver, intestinal) may be observed. Chronicity induces intestinal mucosal atrophy and malabsorption of fats and carbohydrates. Proteinlosing enteropathy may result in hypoproteinemia leading to nutritional deficiency and cachexia. Most often immunocompetent individuals infected by $S$. stercoralis may remain asymptomatic for a long period, but a change in immune status can increase the parasite burden leading to disease manifestation, hyperinfection syndrome and disseminated infection especially in immunocompromised individuals.

The term hyperinfection is used to denote autoinfection, a phenomenon in which the number of worms increases tremendously leading to dissemination. Disseminated disease is defined by the presence of parasites outside of the traditional life cycle (i.e. in organs other than the skin, GI tract, or lungs). Patients with suppressed immunity due to corticosteroids therapy or associated with HIV infection can develop a severe disseminated form. Disseminated strongyloidiasis involves widespread dissemination of larvae outside of the gut and lungs, often involving the liver, brain, heart, and urinary tract, pancreas and central nervous system. In such severe cases which results in severe damage to the intestinal wall due to a high parasite burden, about $50 \%$ of patients with disseminated strongyloidiasis are prone to develop polymicrobial bacteremia often complicated by meningitis [4, 6, 10,11, 20, 22].

Strongyloidiasis is classified under the diagnosis code ICD-10: B78 which highlights:

- Intestinal strongyloidiasis (B78.0);

- Cutaneous strongyloidiasis (B78.1);

- Disseminated strongyloidiasis (V78.7);

- Unspecified strongyloidiasis (B78.9).

The exact incubation period is not known. The early larval migration phase, which occurs during percutaneous infection, lasts up to 10 days. The manifestation reflects the migration of the parasite within the host. Penetration of the skin by filariform larvae may result in the development of a pruritic, papular, erythematous rash. Cough, shortness of breath, wheezing, and fever may develop as the larvae pass through the lungs. In the late phase, when the parasite reaches reproductive maturity and invades the intestine, the clinical manifestations of the disease are associated with damage to the digestive system. In the absence of treatment and possibility of autoinfection, helminthiasis becomes chronic, lasting for years and decades.

Some of these chronic infections have lasted over 30 years as a result of autoinfection.

Patients with mild forms of strongyloidiasis usually present with nausea and epigastric pain.

Stool consistency is unchanged, although constipation or diarrhea can develop. Nausea, sometimes 
accompanied by vomiting, is noted especially in severe signs of the disease. Severe signs also include intense epigastric pain or diffuse abdominal pain, while diarrhea persists for 5-7 days. Patients may present with 15 or more loose or watery stools per day, with signs of dehydration. Passage of bloody stools with mucus is not uncommon in strongyloidiasis. Neurological manifestations associated with strongyloidiasis include headache, dizziness, fatigue and irritability.

Severe allergic syndrome is characterized by persistent recurrent urticaria, itchy skin, myalgia and arthralgia. Eosinophilic myocarditis and asthmatic bronchitis are detected in some patients. Ocular disorders like conjunctivitis, angioretinopathy, inflammatory macular diseases and corneal ulcers has been recorded

Hyperinfection is characterized by severe gastrointestinal and pulmonary manifestations; cramping abdominal pain, watery diarrhoea, weight loss, nausea, vomiting and occasionally gastrointestinal bleeding, asthma-like symptoms such as cough and wheezing, and others such as pneumonia and pulmonary haemorrhage with diffuse bilateral infiltrates on the chest X-ray. CNS involvement (parasitic and bacterial meningitis) and gram-negative sepsis in strongyloidiasis has only been seen in patients with hyperinfection and may be fatal.

Disseminated strongyloidiasis are most frequently associated with subclinical infection in an immunocompromised host. In disseminated strongyloidiasis the larvae invade numerous organs (intestines, lungs, liver, etc.). Immune disorders often disguise typical manifestations of helminthiasis leading to delayed diagnosis and adequate treatment of the disease. Eosinophilia and allergic reactions which are unique among helminths are usually mild or absent.

Complications such as ulcerative intestinal lesions and perforated peritonitis are recorded are associated with strongyloidiasis. It should be noted that existing treatments can provoke inflammatory responses probably due to an immune response to the dead parasites, thus the above complications could be as a result of antiparasitic medication.

Bowel obstruction, appendicitis, pancreatitis, malabsorption are rare complications of $S$. stercoralis infection. In disseminated strongyloidiasis and severe hyperinfection, the mortality rate can be as high as $80 \%[9,18,21,22]$.

The clinical presentation of chronic and acute strongyloidiasis varies from asymptomatic infection, mild symptomatic and severe form [1, 4, 6, 8, 11, 14].

Based on 34 clinical observations, our data revealed 11 mild cases, 21 moderate and 2 severe forms of $S$. stercoralis infection induced by hyperinfection syndrome and disseminated strongyloidiasis. Acute onset of the disease was observed only in 8 patients while a mild onset was frequently recorded.

Case study 1: A 54 years old (y/o) man presents for routine check-up evaluation. He had no chief complaints on examination. There were no skin le- sions and no organ enlargement was noted. Vital signs are as follows: Blood Pressure 130/80mmHg; Heart Rate 78/minute and regular; Respiratory Rate $18 /$ minute. Lungs were clear to auscultation bilaterally and normal S1 and S2 sounds were heard with regular rate and rhythm. Bowel movement and urine output were normal. His complete blood count was only significant for eosinophilia (13\%). He has a history of myocardial infarction and diabetes. He resides in Moscow Region in an apartment and his travel history includes: Australia, Kenya, Kamchatka, Mordovia, Sochi (Southern Russia). A study was conducted to find out the prevalence of any enteric parasites in stool. Results indicated the presence of a low intensity of $S$. stercoralis infection. Examination of stool sediment revealed only 1 rhabditiform larva.

In the presented clinical case, the only significant finding was blood eosinophilia. It should be noted that a rise in the eosinophils is common only among recently infected patients $[1,7,14]$.

In acute strongyloidiasis, the manifestation produces a symptom complex of an acute infectious-allergic presentation within the skin, along with disorders of the gastrointestinal tract, as mentioned above. After 2-3 months, the above symptoms subside, and the disease becomes chronic, characterized by polymorphism of clinical manifestations [4, 6, 7, 9, 14, 22].

Case study 2: A $47 \mathrm{y} / \mathrm{o}$ patient presents with symptoms of nausea, pain in the right and left hypochondriac region, pruritus, and diarrhoea up to 7 times daily. The patient considers himself ill for about 4 years. He has a history of chronic cholecystitis and he has been under constant observation at a gastroenterologist. He was treated without any positive outcome. His travel history includes: multiple visits to China, the Dominican Republic, as well Krasnodar Territory of the Russian Federation. Blood count indicated an eosinophil level of $5.2 \%$, other indicators were not significant. Examination of stool sediment revealed 2 larvae of $S$. stercoralis. Considering his travel history, clinical manifestations and laboratory findings, the patient was diagnosed with intestinal strongyloidiasis.

The described case illustrates by the chronic course of strongyloidiasis with a polymorphic clinical presentation: gastrointestinal disorders (chronic diarrhea and symptoms of dyspepsia) and allergic manifestations.

In severe forms, prolonged diarrhoea syndrome is common, leading to dehydration, malabsorption, anaemia and cachexia. There are possibilities of ulcerative intestinal lesions, parenchymal liver degeneration and pancreatitis

Case study 3: A 48 y/o man presents with the history of chronic diarrhoea up to 8 times daily for five years. He resides in Baku Azerbaijan and constantly visits rural areas of the country. The patient has lost nearly $20 \mathrm{~kg}$ of body weight. He has been under observation at the Institute of Gastroenterology, Moscow, and was diagnosed to have chronic enteri- 
tis. Following treatment, a short-term improvement was noted. Subsequently, diarrhoea and weight loss resumed. The following year he was admitted to the hospital for a history of chronic diarrhoea. Small bowel biopsy was performed and histological examination revealed inflammation response due to eosinophils, a helminth larva, presumably the larva of S. stercoralis. Parasitological method based on the Baermann funnel technique was used to uncover a large number of $S$. stercoralis larvae. Complete blood count revealed high eosinophil levels: $12-18 \%$. The diagnosis of Strongyloides stercoralis hyperinfection was made based on the results obtained.

As mentioned above, immunocompromised patients (HIV infection, radiotherapy followed by chemotherapy, patients on long term corticosteroids use), has unfavourable prognosis as penetration of the larvae is observed not only into the targeted organs (guts and lungs). Brain involvement may lead to venous thrombosis, cerebral oedema and rapid death of the patient. Strongyloidiasis is considered an opportunistic parasitic infection in HIV [4, 6, 10, 17, 21].

It is difficult to make a differential diagnosis of strongyloidiasis based on clinical symptoms due to its polymorphism. Cases of diagnostic errors of were discovered in most of our patients. It was frequently misdiagnosed for cases like food poisoning, bacterial gastroenteritis, unspecified enterocolitis, duodenal ulcer, pancreatitis, biliary dyskinesia, eosinophilic pneumonia and in some cases typhoidal salmonella disease [7, 14]. Lately diseases that conceal the infection are becoming common: Acute leukaemia, malignant neoplasms, Crohn's disease, Whipple syndrome, traveller's diarrhoea [12, 16]. Strongyloidiasis should be differentiated from other helminth infections that have an acute phase in their clinical course (hookworm, ascariasis, schistosomiasis, opisthorchiasis, fascioliasis, clonorchiasis, trichinosis) $[4,6,11]$.

We report a differential diagnosis case report on a 21 years old patient (female) who returned from Thailand with chief complaints of abdominal discomfort and loose stool. The patient presented to a gastroenterologist with these complaints who drew attention to mild eosinophilia (12\%) in her blood count.

Suspected helminth infection prompted the doctor to perform series of serological test and high levels of antibodies to echinococcus were detected. The patient was consulted by an infectious disease (ID) specialist. Further epidemiological, clinical and laboratory data were collected, however human echinococcosis was not confirmed. Subsequent results demonstrated 55\% eosinophilia, moderate leukocytosis and anaemia $(99 \mathrm{~g} / \mathrm{L})$. The patient stated that she had noticed an itchy rash on the tops of her feet and legs while in Thailand. Considering the patient's clinical manifestation, travel history and laboratory findings she was likely to acquire an infection by a geohelminth pathogen. Ancylostoma eggs were identified using
Baermann funnel technique. She was diagnosed with Hookworm infection (Ancylostomiasis) and treatment with albendazole was initiated. The management of the patient was carried out in accordance with the Clinical Guidelines for Management of Patients with Hookworm infection. Follow up of hematological parameters indicated normal values. This case illustrates similar acute infection of geohelminths, the low specificity of serological tests and the importance of constantly investigating pathogens using adequate parasitological methods like the Baermann funnel technique $[2,3,5,6,16]$.

It is important to highlight that patients with strongyloidiasis might present with normal white blood cells (WBC) or moderate leukocytosis. Other possible findings include; Low platelets count, slightly increased ESR, hypochromic anaemia especially in chronic forms. Coprology test reveals a significant amount of muscle fibres and WBC. Besides the stool and duodenal contents, Strongyloides larvae can be detected in the sputum, urine and vomitus of an infected individual $[3,5,6,11,16]$.

The most convenient and widely used method for diagnosing strongyloidiasis is the enzyme-linked immunosorbent assay (ELISA), although specificity may decrease as a result of cross-reactivity with other parasite antigens. Immunological tests have been used primarily as auxiliary methods in combination with clinical laboratory and instrumental techniques. Polymerase chain reaction (PCR) has not been suitable for screening purpose in practice [6, 22].

Medical treatment should be achieved in all cases even in the absence of symptoms to prevent parasite dissemination. Unfortunately, a spontaneous cure is impossible due to the possibility of autoinfection $[6,11,14,22]$. The drug of choice for acute, chronic, hyperinfection and disseminated strongyloidiasis is Ivermectin (stromectol and mectizan available in 3-mg and 6-mg tablets respectively) [22].

Ivermectin is taken as two single $200 \mathrm{mg} / \mathrm{kg}$ doses administered on two consecutive days for adults. Recommended dosage for children aged $<2$ years is $200 \mathrm{mg}$ daily for two days. Some individuals may require a repeated course of treatment if necessary. Ivermectin has been included in the WHO list of essential medicines since 2017. Ivermectin remains unregistered in the Russian Federation. Albendazole is a reasonable alternative although cure rates in clinical trials were inferior to Ivermectin. Albendazole is generally taken as a single dose or two single doses of $400 \mathrm{mg} / 800 \mathrm{mg}$ (after meals) for 3 days. Antihistamines should be considered while on antithelmintic medications. Because of the risk of hyperinfection and/or disseminated disease corticosteroids must be avoided [4, 6, 11]. The management of the diseases is determined by the severity of and complications [13].

Follow-up stool tests (3 times with an interval of 1-2 days) are recommended immediately af- 
ter and one month after the course of medication to determine the effectiveness of therapy. The lesser the fecal test control, the higher the chances (70\%) of false negative results. It is important to note that duodenal aspirate is more sensitive than stool examination. Therefore, when in doubt it is advisable to perform a test on the duodenal contents [4, $6,13]$. The criteria for cure are reached when symptoms finally cease with the disappearance of the parasites from the feces and/or duodenal aspirate.

Strongyloidiasis carries a relatively good prognosis except in severe forms of the disease and immunodeficiency cases which predispose individuals to severe strongyloidiasis [4, 6, 10, 11, 22].

A unifying diagnosis for strongyloidiasis cannot be certain due to its polymorphism and non-speci- ficity of its clinical manifestations. Other factors like the lack of clinician knowledge about the disease and the high importance to implement diagnostic approaches like the use of specific methods, intended for detection of helminth larvae (Baermann technique and its modifications) have a huge impact in disease control. Ivermectin is unlicensed in the Russian Federation and albendazole which serves as the alternative is as least as effective. Therefore, it is mandatory to initiate a repeated course of Albendazole after the initial course is completed in order to establish full recovery from the disease. Considering the global prevalence of Strongyloides infection, the increase in net migration and tourism from affected regions, the disease remains relevant in clinical practice.

\section{References}

1. Бронштейн А.М., Федянина Л.В., Малышев Н.А., Лашин В.М., Бурова С.В., Давыдова И.В., Максимова М.С., Соколова А.В. Острый и хронический стронгилоидоз у российских туристов, посетивших Тайланд, Черноморское побережье Краснодарского края и Абхазии: проблемы диагностики и лечения. Анализ случаев и обзор литературы // Эпидемиология и инфекционных болезней. 2017. Т. 22, № 3. С. 156-161. [Bronstein A.M., Fedyanina L.V., Malyshev N.A. Lashin V.M., Burova S V., Davydova I.V., Maksimova M.S., Sokolova A.V. Acute and chronic strongyloidiasis in Russian tourists travelled to Thailand, the coast of Black sea in Russia and Abkhazia: problems of diagnosis and treatment. Analysis of cases and review. Epidemiologiya i infektsionnykh boleznei = Epidemiology and Infectious Diseases, 2017, vol. 22, no. 3, pp. $156-161$. doi: 10.18821/1560-9529-2017-156-161 (In Russ.)]

2. Головченко Н.В., Ермакова Л.А., Пшеничная Н.Ю., Костенич О.Б., Киосова Ю.В., Журавлев А.С. Клинико-эпидемиологические особенности инвазии Strongyloides stercoralis в Ростовской области // Инфекционные болезни: новости, мнения, обучение. 2018. Т. 7, № 4. С.25-28 [Golovchenko N.V., Ermakova L.A., Pshenichnaya N.Yu., Kostenich O.B., Kiosova Yu.V., Zhuravlev A.S. Clinical and epidemiological features of the invasion of Strongyloides stercoralis in the Rostov Region. Infektsionnye bolezni: novosti, mneniya, obuchenie = Infectious Diseases: News, Opinions, Training, 2018, vol. 7, no. 4. pp. 25-28. doi: 10.24411/2305-3496-2018-14003 (In Russ.)]

3. Ершова И.Б., Осычнок Л.М., Мочалова А.А. Методы диагностики гельминтозов на современном этапе // Актуальная инфектология. 2014. Т. 2, № 3. С. 86-89. [Ershova I.B., Osychnok L.M., Mochalova A.A. Methods of helminthiasis diagnosis at the present stage. Aktual'naya infektologiya = Actual Infectology, 2014, vol. 2, no. 3, pp. 86-89. (In Russ.)]

4. Инфекционные болезни: национальное руководство. Под ред. Н.Д. Ющука, Ю.Я. Венгерова. 2-е изд., перераб. и доп. М.: ГЭОТАР-Медиа, 2019. 1104 с. [Infectious diseases: national guidelines. Eds. Yushchuk N.D., Vengerov Yu.Ya. Moscow: GEOTAR-Media, 2019. 1104 p. (In Russ.)]

5. Лабораторная диагностика гельминтозов и протозоозов. Методические указания МУК 4.2.3145-13. Федеральный центр гигиены и эпидемиологии Роспотребнадзора, 2014. [Laboratory diagnostics of helminthiasis and protozoa. Methodical instructions MUK 4.2.3145-13. Federal Center of Hygiene and Epidemiology of Rospotrebnadzor, 2014. (In Russ.)]

6. Паразитарные болезни человека (протозоозы и гельминтозы): Руководство для врачей. Под ред. В.П. Сергиева, Ю.В. Лобзина, С.С. Козлова. СПб.: Издательство «Фолиант», 2016. 640 с. [Human parasitic diseases (protozoosis and helminthiasis): a guide for physicians. Eds. Sergiev V.P., Lobzin Yu.V., Kozlov S.S. St. Petersburg: Publishing House "Foliant”, 2016. 640 p. (In Russ.)]

7. Полозок Е.С., Токмалаев А.К. О клинике и диагностике стронгилоидоза. Советская медицина. 1978. Т. 5. С. $120-132$. [Polozok E.S., Tokmalaev A.K. About the clinic and diagnosis of strongyloidosis. Sovetskaya meditsina $=$ Soviet Medicine, 1978, vol. 5, pp. 120-132. (In Russ.)]

8. Полякова В.Е., Иванова И.А., Полякова Н.Р., Воробьева М.Л., Полякова Н.В., Ромих В.В. Стронгилоидоз у детей. Педиатрия. 2015. T. 94, № 5. С. 120-126. [Polyakova E.V., Ivanova I.A., Polyakova N.R., Vorobyeva L.M., Polyakova N.V. Romikh V.V. Strongyloidiasis in children. Pediatriya = Pediatrics, 2015, vol. 94, no. 5, pp. 120-126. (In Russ.)]

9. Сергиев В.П., Ющук Н.Д., Венгеров Ю.Я., Завойкин В.Д. Тропические болезни. Пособие для врачей. М.: БИНОМ, 2015. 636 c. [Sergiev V.P., Yushchuk N.D., Vengerov Yu.Ya., Zavoykin V.D. Tropical diseases. Manual for Physicians. Moscow: BINOM, 2015. 636 p. (In Russ.)]

10. Токмалаев А.К., Кожевникова Г.М. Инфекционные и паразитарные болезни у ВИЧ-позитивных лиц. М.: РУДН, 2012. 280 c. [Tokmalaev A.K., Kozhevnikova G.M. Infectious and parasitic diseases in HIV-positive individuals. Moscow: RUDN, 2012. 280 p. (In Russ.)]

11. Токмалаев А.К., Кожевникова Г.М. Клиническая паразитология. Протозоозы и гельминтозы. М.: Медицинское информационное агенство. 2017. 392 с. [Tokmalaev A.K., Kozhevnikova G.M. Clinical Parasitology. Protozoa and helminthiasis. Moscow: Medical News Agency, 2017. 392 p. (In Russ.)]

12. Тумольская Н.И., Голованова Н.Ю., Мазманян М.В., Завойкин В.Д. Клинические маски паразитарных болезней. Инфекционные болезни: новости, мнение, обучение. 2014. № 1. C. 17-27 [Tumolskaya N.I., Golovanova N.Yu., 
Mazmanyan M.V., Zavoykin V.D. The clinical masks of parasitic diseases. Infektsionnye bolezni: novosti, mneniya, obuchenie = Infectious Diseases: News, Opinions, Training, 2014, vol. 1, pp. 17-27. (In Russ.)]

13. Федеральная служба по надзору в сфере защиты прав потребителей и благополучия человека. Письмо о заболеваемости геогельминтозами в РФ в 2015 № 01/13265-16-27 от 03.10.2016. [Federal service for supervision of consumer rights protection and human well-being. Letter on incidence of geohelminthiasis in Russia in 2015 No. 01/13265-16-27 from 03.10.2016]. URL: http://docs.cntd.ru/document/420382145

14. Шабловская Е.А. Стронгилоидоз М.: Медицина, 1986. 128 с. [Shablovskaya E.A. Strongyloidiasis. Moscow: Medicine, 1986. 128 p. (In Russ.)]

15. Atlanta, GA: Centers for Disease Control and Prevention. Parasites - Strongyloides, 2016. URL: https://www.cdc.gov/parasites/ strongyloides/health_professionals/index.html(13.03.2018)

16. Bronshteyn A.M., Malyshev N.A. Traveller's diarrhea caused by ankylostomiasis in a Russia's tourist who has visited Thailand. Epidemiology and Infection, 2009, vol. 3, pp. 35-37.

17. Natrajan K., Medisetty M., Gawali R., Tambolkar A., Patel D., Thorat V., Dubale N., Khirid V., Saraf C., Dravid A. Strongyloidosis hyperinfection syndrome in an HIV-infected patient: a rare manifestation of immune reconstitution inflammatory syndrome. Case Reports in Infectious Diseases, vol. 2018: 6870768, 4 p. doi: 10.1155/2018/6870768

18. Keiser P.B., Nutman T.B. Strongyloides stercoralis in the immunocompromised population. Clin. Microbiol. Rev., 2004, vol. 17, no. 1, pp. 208-217. doi: 10.1128/cmr.17.1.208-217.2004

19. Merman E., Siddha S., Keystone J.S., Habeet A. Cutaneus Strongyloides infection postchemotherapy. J. Cutan. Med. Surg., 2016, vol. 20, pp. 337-339. doi: 10.1177/1203475416633693

20. Ting-ting Q., Yang Q., Yu M.-H., Wang J. A fatal strongyloides stercoralis hyperinfection syndrome in a patient with chronic kidney disease. A case report and literature review. Medicine (Baltimore), 2016, vol. 95, no. 19: 3638. doi: 10.1097/MD.0000000000003638

21. Woll F., Gotuzzo E., Montes M. Strongyloides stercoralis infection complicative the central nervous system. Handbook of Clinical Neurology, 2013, vol. 114, pp. 229-234. doi: 10.1016/B978-0-444-53490-3.00017-0

22. World Gastroenterology Organisation: Global practical recommendations of the World Gastroenterology Organization. The management of strongyloidiasis. February 2018. URL: https://www.worldgastroenterology.org/guidelines/global-guidelines/managementof-strongyloidiasis

23. World Health Organization. Soil-transmitted helminth infections. Geneva: World Health Organization, 2017. URL: https://www. who.int/news-room/fact-sheets/detail/soil-transmitted-helminth-infections (13.03.2018)

\section{Авторы:}

Токмалаев А.К., д.м.н., профессор, профессор кафедры инфекционных болезней с курсами эпидемиологии и фтизиатрии ФГАОУ ВО Российский университет дружбы народов, Москва, Россия;

Кожевникова Г.М., д.м.н., профессор, зав. кафедрой инфекционных болезней с курсами эпидемиологии и фтизиатрии ФГАОУ ВО Российский университет дружбы народов, Москва, Россия;

Завойкин В.Д., д.м.н., профессор, зав. клиническим отделением медицинской паразитологии и тропической медицины Института медицинской паразитологии, тропических и трансмиссивных заболеваний им. Е.И. Марциновского Первого Московского государственного медицинского университета им. И.М. Сеченова, Москва, Россия;

Тумольская Н.И., д.м.н., профессор клинического отделения медицинской паразитологии и тропической медицины Института медицинской паразитологии, тропических и трансмиссивных заболеваний им. Е.И. Марциновского Первого Московского государственного медицинского университета им. И.М. Сеченова, Москва, Россия;

Половинкина Н.А., к.м.н., доцент кафедры инфекционных болезней с курсами эпидемиологии и фтизиатрии ФГАОУ ВО Российский университет дружбы народов, Москва, Россия; Коннов В.В., ассистент кафедры инфекционных болезней с курсами эпидемиологии и фтизиатрии ФГАОУ ВО Российский университет дружбы народов, Москва, Россия;

Голуб В.П., к.м.н., доцент кафедры инфекционных болезней с курсами эпидемиологии и фтизиатрии ФГАОУ ВО Российский университет дружбы народов, Москва, Россия;

Харламова Т.В., к.м.н., ассистент кафедры инфекционных болезней с курсами эпидемиологии и фтизиатрии ФГАОУ ВО Российский университет дружбы народов, Москва, Россия; Емероле К.Ч., к.м.н., ассистент кафедры инфекционных болезней с курсами эпидемиологии и фтизиатрии ФГАОУ ВО Российский университет дружбы народов, Москва, Россия.

\section{Authors:}

Tokmalaev A.K., PhD, MD (Medicine), Professor, Department of Infectious Diseases with Courses of Epidemiology and Phthisiology, Peoples' Friendship University of Russia (RUDN University), Moscow, Russian Federation;

Kozhevnikova G.M., PhD, MD (Medicine), Professor, Head of Department Infectious Diseases with Courses of Epidemiology and Phthisiology, Peoples' Friendship University of Russia (RUDN University), Moscow, Russian Federation;

Zavoikin V.D., PhD, MD (Medicine), Professor, Head of the Department of Medical Parasitology and Tropical Medicine, I.M. Sechenov First Moscow State Medical University, Moscow, Russian Federation;

Tumolskaya N.I., PhD, MD (Medicine), Professor, Department of Medical Parasitology and Tropical Medicine, I.M. Sechenov First Moscow State Medical University, Moscow, Russian Federation; Polovinkina N.A., PhD (Medicine), Associate Professor, Department of Infectious Diseases with Courses of Epidemiology and Phthisiology, Peoples' Friendship University of Russia (RUDN University), Moscow, Russian Federation;

Konnov V.V., Assistant Professor, Department of Infectious Diseases with Courses of Epidemiology and Phthisiology, Peoples' Friendship University of Russia (RUDN University), Moscow, Russian Federation;

Golub V.P., PhD (Medicine), Associate Professor, Department of Infectious Diseases with Courses of Epidemiology and Phthisiology, Peoples' Friendship University of Russia (RUDN University), Moscow, Russian Federation;

Kharlamova T.V., PhD (Medicine), Assistant Professor, Department of Infectious Diseases with Courses of Epidemiology and Phthisiology, Peoples' Friendship University of Russia (RUDN University), Moscow, Russian Federation;

Emerole K.C., PhD (Medicine), Assistant Professor, Department of Infectious Diseases with Courses of Epidemiology and Phthisiology, Peoples' Friendship University of Russia (RUDN University), Moscow, Russian Federation.

Received 17.06.2019

Revision received 11.11.2019

Accepted 14.03.2020 